\title{
Methane Emissions from Subtropical and Tropical Mangrove Ecosystems in Taiwan
}

\author{
Chiao-Wen Lin ${ }^{1}$, Yu-Chen Kao, Meng-Chun Chou, Hsin-Hsun Wu, Chuan-Wen Ho and \\ Hsing-Juh Lin * (D) \\ Department of Life Sciences and Innovation and Development Center of Sustainable Agriculture, National \\ Chung Hsing University, Taichung 40227, Taiwan \\ * Correspondence: hjlin@dragon.nchu.edu.tw; Tel.: +886-4-2284-0416 (ext. 510)
}

Received: 27 February 2020; Accepted: 16 April 2020; Published: 21 April 2020

\begin{abstract}
Mangroves are one of the blue carbon ecosystems. However, greenhouse gas emissions from mangrove soils may reduce the capacity of carbon storage in these systems. In this study, methane $\left(\mathrm{CH}_{4}\right)$ fluxes and soil properties of the top $10 \mathrm{~cm}$ layer were determined in subtropical (Kandelia obovata) and tropical (Avicennia marina) mangrove ecosystems of Taiwan for a complete seasonal cycle. Our results demonstrate that $\mathrm{CH}_{4}$ emissions in mangroves cannot be neglected when constructing the carbon budgets and estimating the carbon storage capacity. $\mathrm{CH}_{4}$ fluxes were significantly higher in summer than in winter in the Avicennia mangroves. However, no seasonal variation in $\mathrm{CH}_{4}$ flux was observed in the Kandelia mangroves. $\mathrm{CH}_{4}$ fluxes were significantly higher in the mangrove soils of Avicennia than in the adjoining mudflats; this trend, however, was not necessarily recapitulated at Kandelia. The results of multiple regression analyses show that soil water and organic matter content were the main factors regulating the $\mathrm{CH}_{4}$ fluxes in the Kandelia mangroves. However, none of the soil parameters assessed show a significant influence on the $\mathrm{CH}_{4}$ fluxes in the Avicennia mangroves. Since pneumatophores can transport $\mathrm{CH}_{4}$ from anaerobic deep soils, this study suggests that the pneumatophores of Avicennia marina played a more important role than soil properties in affecting soil $\mathrm{CH}_{4}$ fluxes. Our results show that different mangrove tree species and related root structures may affect greenhouse gas emissions from the soils.
\end{abstract}

Keywords: Avicennia marina; Kandelia obovata; greenhouse gas; methane; pneumatophore; soil

\section{Introduction}

Mangroves are distributed in tropical and subtropical coastal zones that provide many essential ecosystem services. Mangroves not only reduce anthropogenic nutrient loading from upstream inputs [1] but also protect the coastline, mitigate erosion from typhoons [2,3], and alleviate the economic losses of coastal residents [4]. Furthermore, mangroves provide coastal fishery resources for humans [5,6] and nursery places for marine organisms [7].

Carbon sequestration is one of the essential ecosystem services of mangroves [8]. Mcleod et al. [9] indicated that mangroves, seagrass beds, and salt marshes are the three main "blue carbon" ecosystems, and the estimated global carbon storage rate was $226 \pm 39 \mathrm{~g} \mathrm{C} \mathrm{m}^{-2} \mathrm{yr}^{-1}$. In addition, the carbon sequestration rate was approximately $1.26 \mathrm{Mg} \mathrm{ha}^{-1} \mathrm{yr}^{-1}$ in mangroves, which was much greater than that of seagrass beds $\left(0.36 \mathrm{Mg} \mathrm{ha}^{-1} \mathrm{yr}^{-1}\right)$ and salt marshes $\left(0.39 \mathrm{Mg} \mathrm{ha}^{-1} \mathrm{yr}^{-1}\right)$ in Australia [10]. Thus, mangroves can play an important role in regulating climate and mitigating global warming.

Anaerobic conditions often develop in the frequently flooded soils of coastal wetlands such as mangroves due to the curtailed supply of atmospheric oxygen into the soils. As a result, oxygen is rapidly depleted, soil oxidation reduction potential (Eh) is reduced, and other oxidants are used as electron acceptors for further respiration [11-13]. Anaerobic processes that follow aerobic 
respiration $\left(\mathrm{O}_{2} \rightarrow \mathrm{CO}_{2}\right)$ include (1) denitrification $\left(\mathrm{NO}_{3}{ }^{-} \rightarrow \mathrm{NO}_{2}{ }^{-} \rightarrow \mathrm{NO} \rightarrow \mathrm{N}_{2} \mathrm{O} \rightarrow \mathrm{N}_{2}\right)$, (2) manganese reduction $\left(\mathrm{Mn}^{4+} \rightarrow \mathrm{Mn}^{2+}\right)$, (3) iron reduction $\left(\mathrm{Fe}^{3+} \rightarrow \mathrm{Fe}^{2+}\right)$, (4) sulfate reduction $\left(\mathrm{SO}_{4}^{2-} \rightarrow \mathrm{H}_{2} \mathrm{~S}\right)$, and (5) methanogenesis $\left(\mathrm{CO}_{2} \rightarrow \mathrm{CH}_{4}\right)$. The greenhouse gases such as $\mathrm{CO}_{2}, \mathrm{~N}_{2} \mathrm{O}$, and $\mathrm{CH}_{4}$ are produced in a chain of reduction reactions by microbial metabolism. Furthermore, since sulfate can be directly acquired from seawater, the reduction reaction of sulfate is generally stronger than methanogenesis at sites immersed in high-salinity seawater, such as mangroves [13]. Consequently, $\mathrm{CH}_{4}$ emissions from mangroves have been reported to be affected by temperature and soil parameters, e.g., salinity, redox potential (ORP), $\mathrm{pH}$, water content, and sulfate content $[14,15]$. However, other factors regulating greenhouse gas emissions from mangroves have seldom been discussed.

Previous studies established the carbon budgets in mangrove ecosystems [16,17]. Nonetheless, neglecting the emissions of greenhouse gas in the carbon budgets could possibly overestimate the carbon storage capacity. Based on an Intergovernmental Panel on Climate Change (IPCC) report [18], the global warming potential of $\mathrm{CH}_{4}$ is 28 times higher than that of carbon dioxide $\left(\mathrm{CO}_{2}\right)$ over 100 years. Thus, to precisely estimate the carbon storage capacity, $\mathrm{CH}_{4}$ emissions should be quantified in mangrove ecosystems $[19,20]$.

There are large areas of mangroves distributed along the western coast of Taiwan. Four mangrove species (Avicennia marina, Kandelia obovata, Lumnizera racemosa, and Rhizophora stylosa) are present in Taiwan. The dominant species are Kandelia obovata and Avicennia marina on the northwest (subtropical) and southwest (tropical) coasts, respectively. The root structures of the two mangrove species differ. Kandelia obovata possesses prop roots, whereas vertical roots or pneumatophores are observed in Avicennia marina. In this study, we hypothesized that $\mathrm{CH}_{4}$ fluxes from the soils of mangrove ecosystems were different among seasons, between habitat types (mangroves and adjoining mudflats), and between mangrove species (Kandelia obovata and Avicennia marina). The main objectives in this study were to (1) determine seasonal variations in soil $\mathrm{CH}_{4}$ flux, (2) compare $\mathrm{CH}_{4}$ fluxes and soil parameters between the mangroves and adjoining mudflats, and (3) compare $\mathrm{CH}_{4}$ fluxes and soil parameters between the mangroves of Kandelia obovata and Avicennia marina.

\section{Materials and Methods}

\subsection{Study Sites}

The four study sites (Figure 1), from north to south, were (1) Xinfeng (XF) (24 $54^{\prime} \mathrm{N}, 120^{\circ} 58^{\prime}$ E), (2) Zhunan (ZN) $\left(24^{\circ} 40^{\prime} \mathrm{N}, 120^{\circ} 50^{\prime} \mathrm{E}\right)$, (3) Budai (BD) $\left(23^{\circ} 21^{\prime} \mathrm{N}, 120^{\circ} 7^{\prime} \mathrm{E}\right)$, and (4) Beimen (BM) $\left(23^{\circ} 17^{\prime} \mathrm{N}, 120^{\circ} 6^{\prime} \mathrm{E}\right)$, where the climate is rainy and hot in summer and dry and mild in winter (Table 1$)$. The dominant mangrove species were Kandelia obovata at XF and ZN (subtropical) and Avicennia marina at $\mathrm{BD}$ and $\mathrm{BM}$ (tropical). Both tree height and density were higher in the Kandelia mangroves than in the Avicennia mangroves (Table 1).

Tides were predominantly semidiurnal off the western coast of Taiwan, and the tidal range increased from the southwest (tropical) to the northwest (subtropical; Table 1). The immersion time during flood tides at the four sites averaged $11.5-13.5 \mathrm{~h} /$ day. The extended mudflats were wider in the Avicennia mangroves than in the Kadelia mangroves. As a result, the area ratios of mangroves to mudflats were higher in the Kadelia mangroves than in the Avicennia mangroves. The mangroves at XF were highly affected by excessive nutrient loading $\left(\mathrm{PO}_{4}{ }^{3-}: 1.30-72.30 \mu \mathrm{M}\right.$ and $\left.\mathrm{NO}_{3}{ }^{-}: 41.48-753.84 \mu \mathrm{M}\right)$ as a consequence of urban sewage (Figure 1 and Table 1 ). The mangroves at BD were categorized into an important wetland reserve, which became a habitat for migratory birds and waterfowl. There were several shellfish farms distributed near the mangroves at BM. 

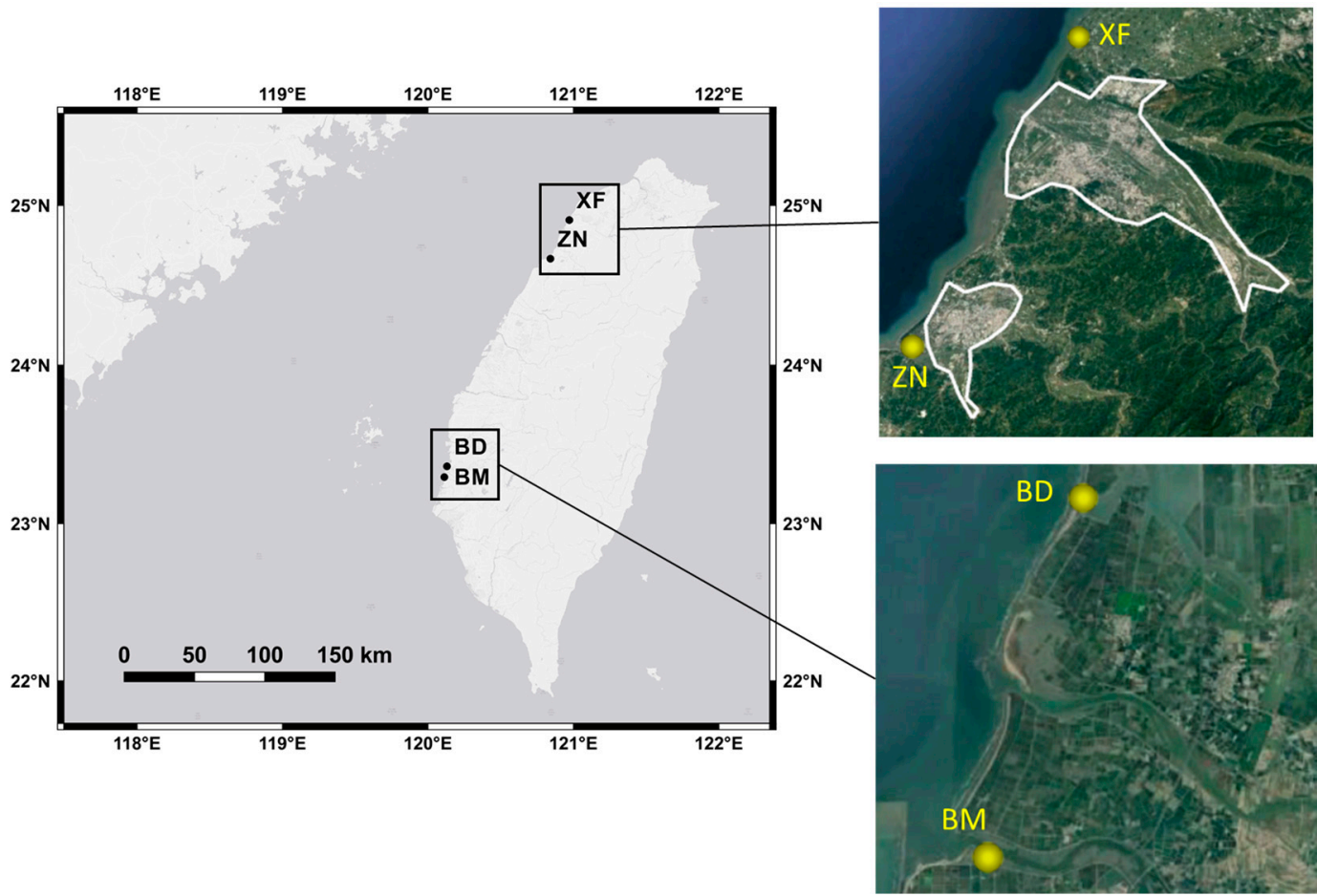

Figure 1. Map of studied mangrove sites at Xinfeng (XF), Zhunan (ZN), Budai (BD), and Beimen (BM) in Taiwan. The urban areas near XF (15,991 ha) and ZN (3807 ha) are shown by the white polygons. Non-urban area was observed near BD or BM. (Map sources: Left: QGIS 2.18.14; Right: Google Earth).

Table 1. Meteorological conditions, mangrove features, soil texture, and water nutrient concentrations at the four mangrove sites: Xinfeng (XF), Zhunan (ZN), Budai (BD), and Beimen (BM).

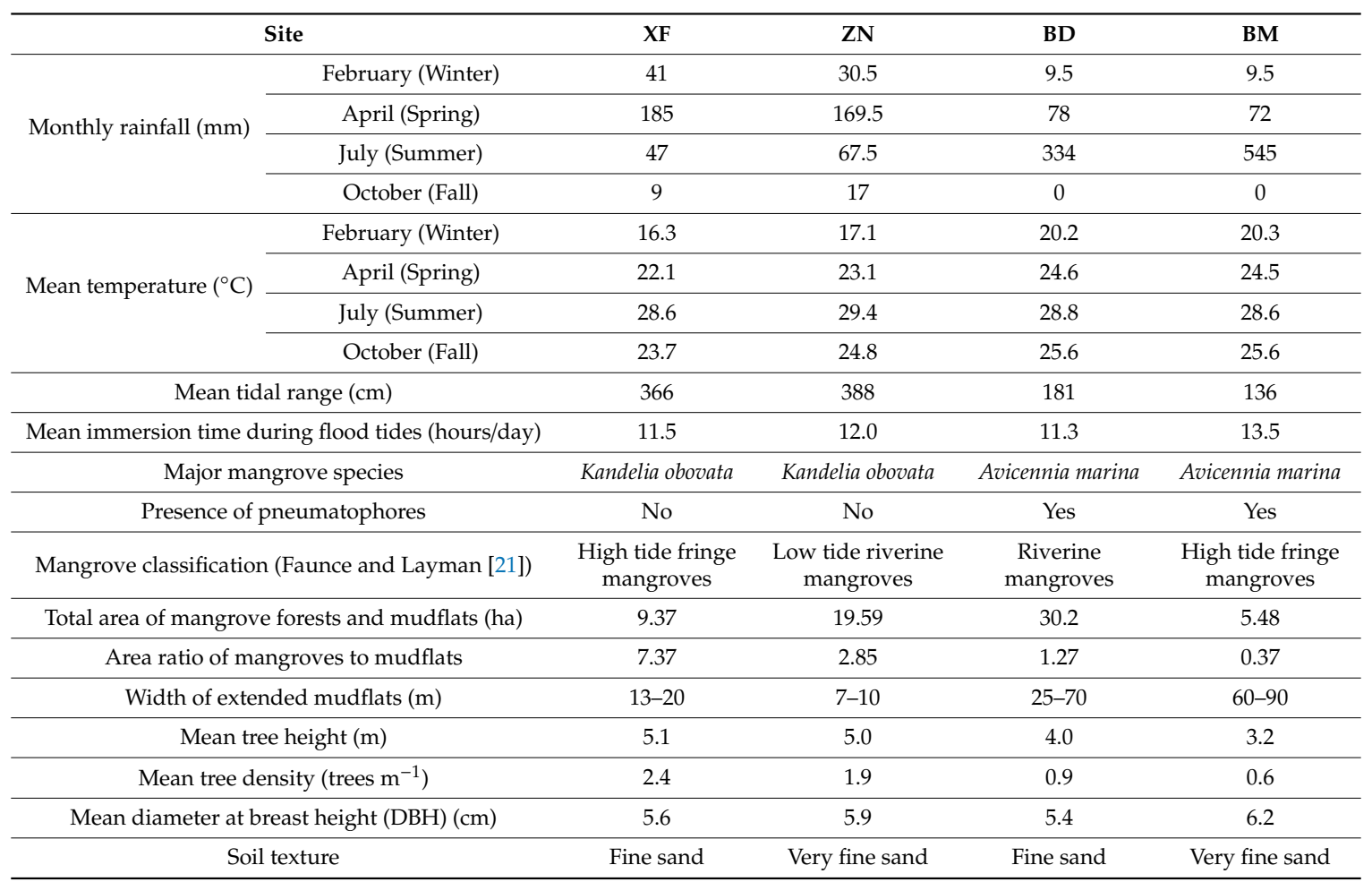


Table 1. Cont.

\begin{tabular}{|c|c|c|c|c|c|}
\hline & & $\mathbf{X F}$ & ZN & BD & BM \\
\hline \multirow{2}{*}{$\mathrm{PO}_{4}^{3-}(\mu \mathrm{M})$} & Range & $1.30-72.30$ & $2.89-18.30$ & $0.91-5.23$ & $1.46-6.93$ \\
\hline & Mean \pm standard error & $29.94 \pm 5.28$ & $8.33 \pm 1.16$ & $3.07 \pm 0.30$ & $3.40 \pm 0.39$ \\
\hline $\mathrm{NO}_{3}{ }^{-}(\mu \mathrm{M})$ & Mean \pm standard error & $300.24 \pm 43.51$ & $8.20 \pm 1.04$ & $4.18 \pm 0.57$ & $11.39 \pm 1.07$ \\
\hline $\mathrm{NO}_{2}^{-}(\mu \mathrm{M})$ & Range & 5.57-97.82 & $0.66-35.22$ & $0.12-2.09$ & $1.99-6.79$ \\
\hline \multirow{2}{*}{$\mathrm{NH}_{4}^{+}(\mu \mathrm{M})$} & Range & $26.10-100.84$ & $93.21-203.75$ & $2.42-17.66$ & $10.62-38.99$ \\
\hline & Mean \pm standard error & $56.08 \pm 4.81$ & $129.94 \pm 6.12$ & $8.59 \pm 0.87$ & $24.16 \pm 1.76$ \\
\hline
\end{tabular}

\subsection{Methane Flux Measurement}

We determined $\mathrm{CH}_{4}$ fluxes and soil parameters for a complete seasonal cycle in February (winter), April (spring), July (summer), and October (fall) in 2019. An in situ closed-path chamber connected with an ultraportable greenhouse gas analyzer (LGR915-0001, Los Gatos Research, San Jose, CA, USA) was used to quantify the $\mathrm{CH}_{4}$ fluxes from the soils in mangrove ecosystems (mangroves and adjoining mudflats) at the four sites during emersion. Measurements of $\mathrm{CH}_{4}$ flux were carried out in 3-5 replicate (5 in most cases) mangrove and adjoining mudflat soil samples (5 in most cases) at each site in each season. The replicated sites for measurements were chosen randomly within the mangroves and mudflats to represent each habitat type. To avoid any potential disturbance, the distance between two replicated sites was at least $5 \mathrm{~m}$. In the field, a semicircular transparent acrylic chamber with a stainless-steel ring ( $30 \mathrm{~cm}$ in diameter and $16 \mathrm{~cm}$ in height) connected with the gas analyzer through a polyvinyl chloride (PVC) tube was pushed into the soil to a depth of $10 \mathrm{~cm}$. The chamber enclosed 10.6 $\mathrm{L}$ of air over a $0.071 \mathrm{~m}^{2}$ surface area. $\mathrm{CH}_{4}$ concentration exchanges between the soil and the atmosphere were monitored by the gas analyzer and recorded by a data logger with a $20 \mathrm{~s}$ logging frequency for $10 \mathrm{~min}$. The $\mathrm{CH}_{4}$ fluxes were calculated by Equation (1).

$$
\mathrm{F}=\frac{S * V * 180 * 24}{(R T * A)}
$$

where, $\mathrm{F}$ : $\mathrm{CH}_{4}$ fluxes ( $\mu \mathrm{mol} \mathrm{CH}_{4} \mathrm{~m}^{-2}$ day $^{-1}$ ), S: slope of the linear regression line between $\mathrm{CH}_{4}$ concentrations (ppm) and recorded frequency $(20 \mathrm{~s}), \mathrm{V}$ : chamber volume (L), R: ideal gas constant = $0.082\left(\mathrm{~L} \mathrm{~atm} \mathrm{~K}^{-1} \mathrm{~mol}^{-1}\right)$, $\mathrm{T}$ : absolute temperature $(\mathrm{K})$, A: the area of the bottom part of the chamber $\left(\mathrm{m}^{2}\right), 180$ : time transformation constant $=(1 \mathrm{~h} \times(60 \mathrm{~min} / \mathrm{hour}) \times((60 \mathrm{~s} / \mathrm{min}) / 20 \mathrm{~s})$, and $24: 1$ day $=24 \mathrm{~h}$.

\subsection{Soil and Water Sampling}

After $\mathrm{CH}_{4}$ measurements at each site in each season, soil parameters in the top $10 \mathrm{~cm}$ layer were determined in 5 replicates in the mangroves and 2 replicates in the adjoining mudflats during emersion. Soil temperature and redox potential (ORP) were measured by a redox potential meter (ORP30, CLEAN L'eau, Taoyuan City, Taiwan), and soil $\mathrm{pH}$ was determined by a portable $\mathrm{pH}$ meter (WD-35634-40, OAKTON Instruments, Vernon Hills, IL, USA) in situ at the four sites during each field visit.

For soil bulk density and water and organic matter content, we collected soil samples by using stainless cores with a $7 \mathrm{~cm}$ diameter and $80 \mathrm{~cm}$ length. The top $10 \mathrm{~cm}$ of the soil core samples were then retrieved as subsamples by applying syringes $2.9 \mathrm{~cm}$ in diameter and $5 \mathrm{~cm}$ in length (syringe volume $=$ $33.0 \mathrm{~cm}^{3}$ ). The subsamples were stored in $50 \mathrm{~mL}$ centrifuge tubes and placed with ice in a portable cooler for laboratory analysis. Each soil subsample was placed on a tin plate $\left(W_{0}\right)$ and weighed as $W_{1}$. The sample with the tin plate was placed in an oven at $60^{\circ} \mathrm{C}$ until a constant dry weight was attained $\left(W_{2}\right)$. The water content and bulk density were calculated by Equations (2) and (3), respectively [17].

$$
\text { Water content }(\%)=\frac{\left(W_{1}-W_{2}\right)}{\left(W_{1}-W_{0}\right)} * 100 \%
$$




$$
\text { Bulk density }\left(\mathrm{g} \mathrm{cm}^{-3}\right)=\frac{\left(W_{2}-W_{0}\right)}{33 \mathrm{~cm}^{3}}
$$

Then, the subsample was placed in an oven at $450{ }^{\circ} \mathrm{C}$ for $4 \mathrm{~h}$ and weighed as $\mathrm{W}_{3}$ as the ash-dried weight. The organic matter content was obtained by Equation (4) [17].

$$
\text { Organic matter }(\%)=\frac{\left(W_{2}-W_{3}\right)}{\left(W_{2}-W_{0}\right)} * 100 \%
$$

Since the soil was too dry to measure the salinity in situ, another subsample was collected from the original core sample and placed in a sealed plastic bag for laboratory analysis. A syringe was used to extract the pore water from the subsample, and the salinity of the pore water was measured by a portable refractometer (Refractometer FG-201, Hangzhou Chincan Trading Co., Ltd., Hangzhou city, Zhejiang province, China).

At the high tide before $\mathrm{CH}_{4}$ measurements at each site in each season, water samples collected for nutrient analysis were filtered in the field through $0.45 \mu \mathrm{m}$ cellulose nitrate membrane filters (GN-6 Metricel, PALL Corporation, Port Washington, NY, USA) and transported back to the laboratory on ice. At the laboratory, these samples were analyzed by a spectrophotometer (U-2001, Hitachi, Japan) for the concentrations of $\mathrm{NO}_{2}{ }^{-}$[22], $\mathrm{NO}_{3}{ }^{-}$[23], $\mathrm{NH}_{4}{ }^{+}$[24], and $\mathrm{PO}_{4}{ }^{3-}$ [25].

\subsection{Statistical Analyses}

Based on the results of the Shapiro-Wilk test, the data of $\mathrm{CH}_{4}$ flux and soil parameters were not normally distributed ( $p$-value $<0.05$ ). Thus, the Kruskal-Wallis test was applied to evaluate seasonal variations in $\mathrm{CH}_{4}$ flux and soil parameters at each site. If the results indicated significance at the 0.05 probability level, the Tukey's honestly significant difference (HSD) test and the Bonferroni correction for the significance level were used to determine which levels differed. The Wilcoxon rank-sum test was used to compare the differences in $\mathrm{CH}_{4}$ flux and soil parameters between (1) mangroves and adjoining mudflats, and (2) the mangroves of Kandelia obovata and Avicennia marina. Multiple regression analysis was implemented to identify the soil parameters that most affected $\mathrm{CH}_{4}$ flux in the mangroves. The statistically significant level was $p<0.05$. The statistical tests in this study were carried out using R software (Version 3.6.1, https://www.r-project.org/) [26].

\section{Results}

\section{1. $\mathrm{CH}_{4}$ Flux and Soil Parameters}

The variations in $\mathrm{CH}_{4}$ flux from the mangrove soils were high: 42.4-1326.6, 1.3-39.3, 10.1-1847.8, and 337.6-7606.6 $\mu \mathrm{mol}-\mathrm{CH}_{4} \mathrm{~m}^{-2}$ day $^{-1}$ at $\mathrm{XF}, \mathrm{ZN}, \mathrm{BD}$, and BM, respectively (Table 2). There were no significant seasonal variations in $\mathrm{CH}_{4}$ flux from the soils of $\mathrm{XF}$ and $\mathrm{ZN}$ mangroves (Figure 2). However, $\mathrm{CH}_{4}$ fluxes from the soils of mangroves were significantly higher in summer than in winter at $\mathrm{BD}$ and $\mathrm{BM}$ (Figure 3). At $\mathrm{XF}, \mathrm{ZN}$, and BM, almost all soil parameters were significantly different among seasons (Table 2). At BD, however, there were no significant seasonal variations in many soil parameters.

$\mathrm{CH}_{4}$ fluxes from the soils of mudflats were 45.2-79.1, 93.9-334.5, 6.6-102.8, and 14.3-192.7 $\mu$ mol$\mathrm{CH}_{4} \mathrm{~m}^{-2}$ day $^{-1}$ at $\mathrm{XF}, \mathrm{ZN}, \mathrm{BD}$, and BM, respectively (Table 3). Seasonal variations in the $\mathrm{CH}_{4}$ flux and soil parameters in the mudflats were smaller than the variations in the mangroves at the four sites. 


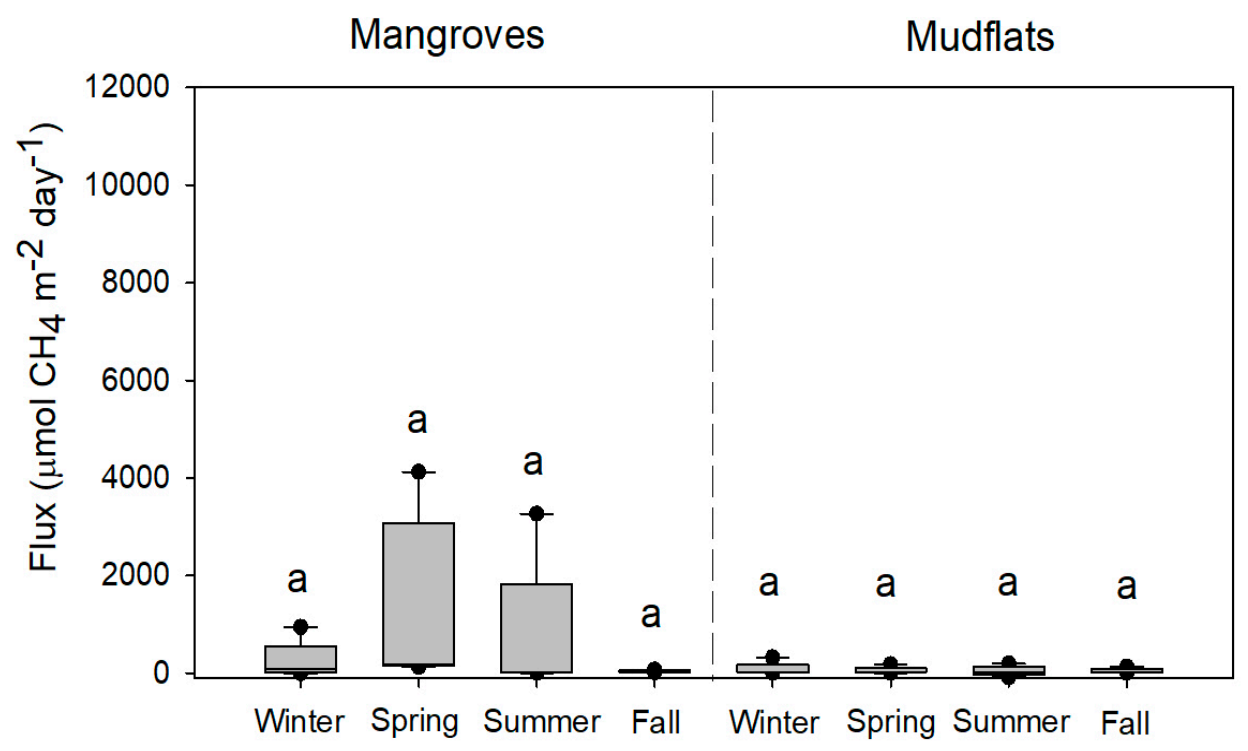

(a) $\mathrm{XF}$

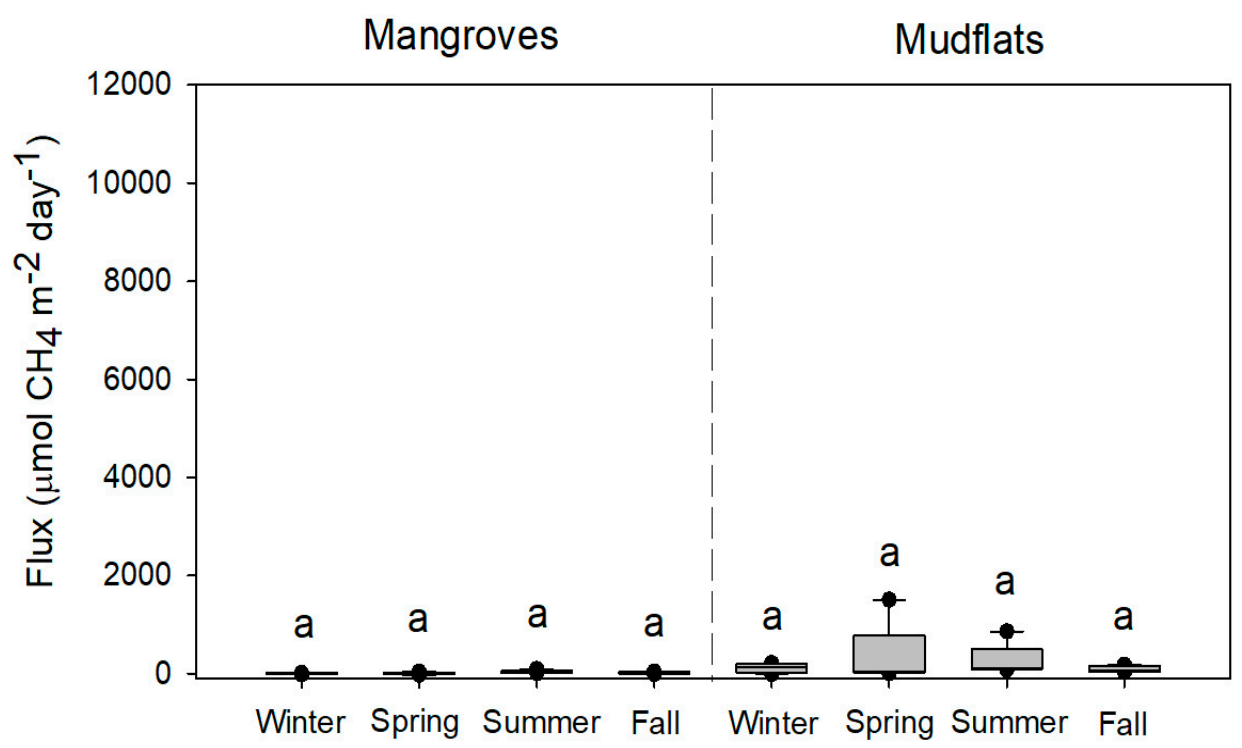

(b) ZN

Figure 2. Methane fluxes $(n=5)$ from the soils of mangroves of Kandelia obovata and adjoining mudflats at (a) Xinfeng (XF) and (b) Zhunan (ZN). Same letters indicate no significant seasonal differences with the Kruskal-Wallis test and Tukey's honestly significant difference (HSD) test and the Bonferroni correction for the significance level in mangroves and mudflats, respectively. 


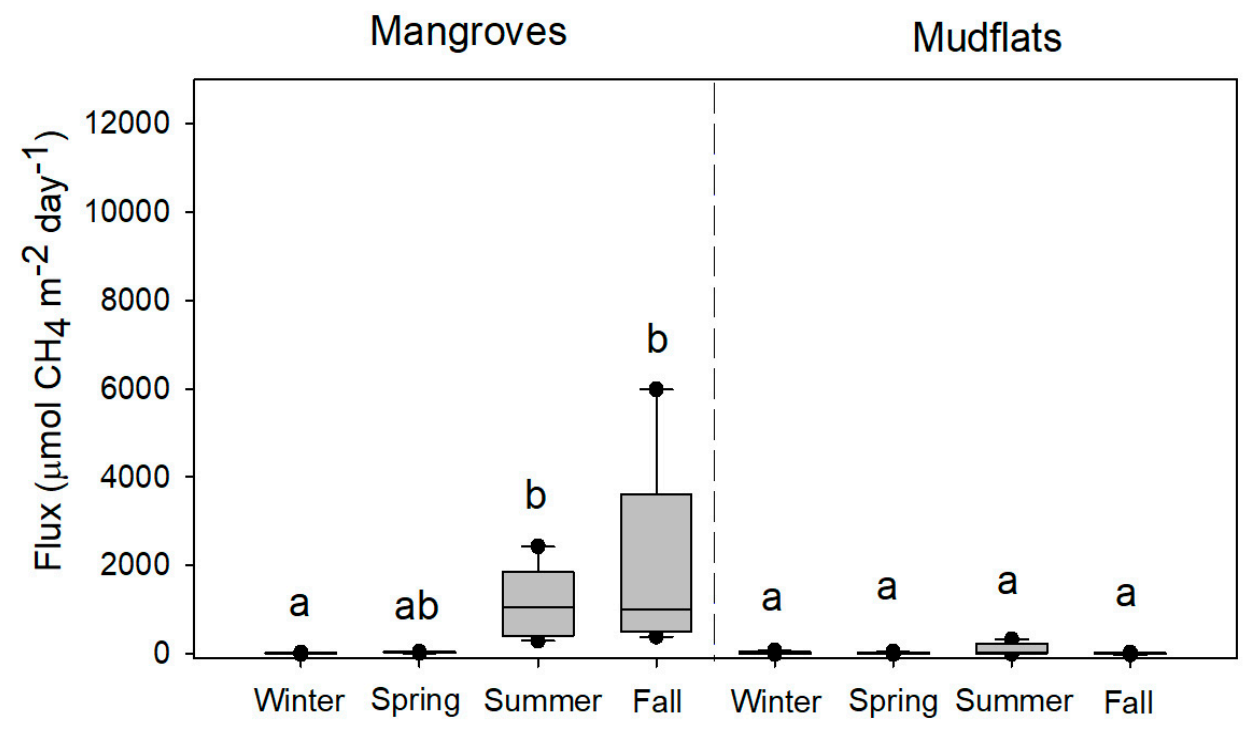

(a) BD

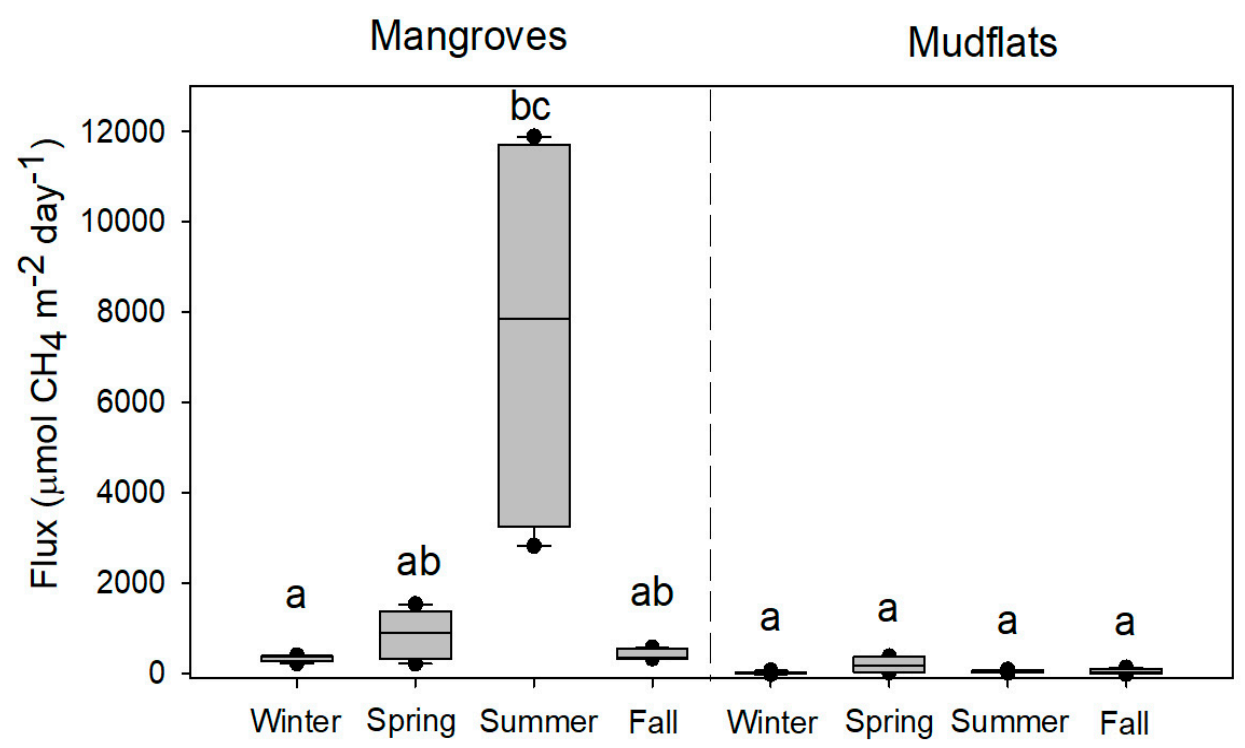

(b) BM

Figure 3. Methane fluxes ( $n=5$ except at BM, where $n=4$ in the summer of mangroves and $n=3$ in the spring of mudflats) from the soils of mangroves of Avicennia marina and adjoining mudflats at (a) Budai (BD) and (b) Beimen (BM). Different letters indicate significant seasonal differences with the Kruskal-Wallis test and Tukey's honestly significant difference (HSD) test and the Bonferroni correction for the significance level in mangroves and mudflats, respectively. 
Table 2. Seasonal variations in methane fluxes and soil physiochemical parameters (Mean \pm standard error) of the four mangrove sites. Different letters indicate significant seasonal differences with the Kruskal-Wallis test and Tukey's honestly significant difference (HSD) test and the Bonferroni correction for the significance level for each mangrove site. ORP: redox potential.

\begin{tabular}{|c|c|c|c|c|c|c|c|c|c|}
\hline \multirow{2}{*}{ Site } & \multirow{2}{*}{ Season } & Methane Fluxes & Temperature & ORP & \multirow{2}{*}{$\mathrm{pH}$} & \multirow{2}{*}{ Salinity } & Bulk Density & Water Content & Organic Matter \\
\hline & & $\left(\mu \mathrm{mol}-\mathrm{CH}_{4} \mathrm{~m}^{-2} \mathrm{day}^{-1}\right)$ & $\left({ }^{\circ} \mathrm{C}\right)$ & $(\mathrm{mV})$ & & & $\left(\mathrm{g} \mathrm{cm}^{-3}\right)$ & $(\%)$ & $(\%)$ \\
\hline \multirow{4}{*}{$X F$} & Winter & $241.6 \pm 178.1 \mathrm{a}$ & $17.5 \pm 0.3 \mathrm{a}$ & $218.2 \pm 16.2 \mathrm{a}$ & $6.4 \pm 0.1 \mathrm{a}$ & $0.4 \pm 0.1 \mathrm{a}$ & $1.5 \pm 0.0 \mathrm{~b}$ & $25.9 \pm 1.5 \mathrm{ab}$ & $3.9 \pm 0.5 \mathrm{a}$ \\
\hline & Spring & $1326.6 \pm 786.9 \mathrm{a}$ & $20.5 \pm 0.1 \mathrm{ab}$ & $171.6 \pm 9.5 \mathrm{a}$ & $6.2 \pm 0.0 \mathrm{a}$ & $0.9 \pm 0.1 \mathrm{ab}$ & $1.0 \pm 0.0 \mathrm{a}$ & $32.9 \pm 1.5 \mathrm{~b}$ & $5.2 \pm 0.4 \mathrm{a}$ \\
\hline & Summer & $742.5 \pm 635.3 \mathrm{a}$ & $28.6 \pm 0.2 c$ & $160.6 \pm 22.9 \mathrm{a}$ & $6.4 \pm 0.1 \mathrm{a}$ & $0.9 \pm 0.1 \mathrm{ab}$ & $1.0 \pm 0.1 \mathrm{a}$ & $34.4 \pm 1.4 \mathrm{~b}$ & $5.5 \pm 0.4 \mathrm{a}$ \\
\hline & Fall & $42.4 \pm 9.1 \mathrm{a}$ & $25.1 \pm 0.5 \mathrm{bc}$ & $183.6 \pm 9.9 \mathrm{a}$ & $6.2 \pm 0.1 \mathrm{a}$ & $1.2 \pm 0.1 \mathrm{~b}$ & $1.2 \pm 0.0 \mathrm{ab}$ & $22.7 \pm 1.2 \mathrm{a}$ & $5.5 \pm 1.0 \mathrm{a}$ \\
\hline \multirow{3}{*}{$\mathrm{ZN}$} & Winter & $1.3 \pm 3.4 \mathrm{a}$ & $17.4 \pm 0.1 \mathrm{a}$ & $139.2 \pm 29.8 \mathrm{ab}$ & $6.6 \pm 0.1 \mathrm{ab}$ & $2.4 \pm 0.3 \mathrm{a}$ & $1.6 \pm 0.0 \mathrm{~b}$ & $23.7 \pm 1.0 \mathrm{ab}$ & $4.1 \pm 0.4 \mathrm{a}$ \\
\hline & Summer & $39.3 \pm 13.3 \mathrm{a}$ & $27.5 \pm 0.1 \mathrm{c}$ & $-3.6 \pm 20.5 a$ & $6.4 \pm 0.1 \mathrm{a}$ & $3.1 \pm 0.3 \mathrm{a}$ & $1.3 \pm 0.0 \mathrm{a}$ & $29.2 \pm 0.9 \mathrm{~b}$ & $3.8 \pm 0.2 \mathrm{a}$ \\
\hline & Fall & $14.5 \pm 9.3 \mathrm{a}$ & $25.7 \pm 0.5 \mathrm{bc}$ & $133.6 \pm 10.6 \mathrm{ab}$ & $7.0 \pm 0.1 \mathrm{~b}$ & $3.1 \pm 0.2 \mathrm{a}$ & $1.4 \pm 0.0 \mathrm{ab}$ & $19.7 \pm 0.6 \mathrm{a}$ & $4.3 \pm 0.4 \mathrm{a}$ \\
\hline \multirow{4}{*}{$\mathrm{BD}$} & Winter & $10.1 \pm 5.5 \mathrm{a}$ & $23.0 \pm 0.0 \mathrm{a}$ & $-274.4 \pm 28.0 \mathrm{a}$ & $7.1 \pm 0.1 \mathrm{~b}$ & $2.9 \pm 0.1 \mathrm{ab}$ & $1.1 \pm 0.2 \mathrm{~b}$ & $43.5 \pm 7.5 \mathrm{a}$ & $5.3 \pm 1.1 \mathrm{a}$ \\
\hline & Spring & $32.0 \pm 5.9 \mathrm{ab}$ & $27.9 \pm 0.2 \mathrm{bc}$ & $-285.0 \pm 9.2 \mathrm{a}$ & $6.7 \pm 0.0 \mathrm{ab}$ & $4.5 \pm 0.3 c$ & $1.1 \pm 0.1 \mathrm{~b}$ & $58.0 \pm 2.1 \mathrm{a}$ & $7.2 \pm 0.4 \mathrm{a}$ \\
\hline & Summer & $1116.6 \pm 372.3 \mathrm{~b}$ & $30.5 \pm 0.4 \mathrm{c}$ & $-340.8 \pm 13.9 a$ & $6.6 \pm 0.1 \mathrm{ab}$ & $2.5 \pm 0.3 \mathrm{a}$ & $0.5 \pm 0.1 \mathrm{a}$ & $57.6 \pm 2.3 \mathrm{a}$ & $8.4 \pm 0.9 \mathrm{a}$ \\
\hline & Fall & $1847.8 \pm 1045.4 \mathrm{~b}$ & $24.5 \pm 0.1 \mathrm{ab}$ & $-290.2 \pm 24.0 \mathrm{a}$ & $6.6 \pm 0.2 \mathrm{a}$ & $3.8 \pm 0.2 \mathrm{abc}$ & $0.8 \pm 0.1 \mathrm{ab}$ & $37.8 \pm 5.5 \mathrm{a}$ & $6.5 \pm 0.5 \mathrm{a}$ \\
\hline \multirow[t]{3}{*}{$\mathrm{BM}$} & Spring & $865.0 \pm 244.5 \mathrm{ab}$ & $27.6 \pm 0.2 \mathrm{bc}$ & $-8.4 \pm 10.8 \mathrm{a}$ & $6.7 \pm 0.1 \mathrm{a}$ & $5.6 \pm 0.8 \mathrm{~b}$ & $2.2 \pm 0.0 \mathrm{~b}$ & $30.8 \pm 1.2 \mathrm{a}$ & $2.6 \pm 0.2 \mathrm{a}$ \\
\hline & Summer & $7606.6 \pm 2304.8 \mathrm{bc}$ & $30.1 \pm 0.4 \mathrm{c}$ & $-151.4 \pm 54.1 \mathrm{a}$ & $7.0 \pm 0.1 \mathrm{a}$ & $3.1 \pm 0.1 \mathrm{a}$ & $1.0 \pm 0.0 \mathrm{a}$ & $38.2 \pm 2.7 \mathrm{a}$ & $3.5 \pm 0.2 \mathrm{ab}$ \\
\hline & Fall & $424.7 \pm 54.5 \mathrm{ab}$ & $23.7 \pm 0.2 \mathrm{ab}$ & $-148.0 \pm 50.3 \mathrm{a}$ & $6.6 \pm 0.1 \mathrm{a}$ & $4.2 \pm 0.4 \mathrm{ab}$ & $1.2 \pm 0.1 \mathrm{ab}$ & $29.5 \pm 3.8 \mathrm{a}$ & $3.3 \pm 0.2 \mathrm{ab}$ \\
\hline
\end{tabular}


Table 3. Seasonal variations in methane fluxes and soil physiochemical parameters (Mean \pm standard error) of the four adjoining mudflats. No significant seasonal difference was detected for all variables at each mudflat site with the Kruskal-Wallis test and Tukey's honestly significant difference (HSD) test and the Bonferroni correction for the significance level. ORP: redox potential.

\begin{tabular}{|c|c|c|c|c|c|c|c|c|c|}
\hline \multirow{2}{*}{ Site } & \multirow{2}{*}{ Season } & Methane Fluxes & Temperature & ORP & \multirow{2}{*}{$\mathrm{pH}$} & \multirow{2}{*}{ Salinity } & \multirow{2}{*}{$\begin{array}{c}\text { Bulk Density } \\
\left(\mathrm{g} \mathrm{cm}^{-3}\right)\end{array}$} & \multirow{2}{*}{$\begin{array}{c}\text { Water Content } \\
(\%)\end{array}$} & \multirow{2}{*}{$\begin{array}{c}\text { Organic Matte } \\
(\%)\end{array}$} \\
\hline & & $\left(\mu \mathrm{mol}-\mathrm{CH}_{4} \mathrm{~m}^{-2} \mathrm{day}^{-1}\right)$ & $\left({ }^{\circ} \mathrm{C}\right)$ & $(\mathrm{mV})$ & & & & & \\
\hline \multirow{4}{*}{$\mathrm{XF}$} & Winter & $79.1 \pm 61.6$ & $17.5 \pm 0.4$ & $-15.5 \pm 30.5$ & $7.1 \pm 0.2$ & $1.7 \pm 0.0$ & $1.1 \pm 0.0$ & $39.9 \pm 0.4$ & $3.2 \pm 0.0$ \\
\hline & Spring & $56.3 \pm 32.1$ & $24.7 \pm 0.9$ & $-62.0 \pm 36.0$ & $6.6 \pm 0.0$ & $2.9 \pm 0.2$ & $1.0 \pm 0.0$ & $36.5 \pm 2.1$ & $3.9 \pm 0.1$ \\
\hline & Summer & $45.2 \pm 46.7$ & $28.6 \pm 0.1$ & $62.5 \pm 86.5$ & $6.9 \pm 0.1$ & $1.8 \pm 0.0$ & $1.1 \pm 0.0$ & $37.8 \pm 0.9$ & $3.8 \pm 0.1$ \\
\hline & Fall & $48.9 \pm 22.4$ & $24.5 \pm 0.1$ & $47.5 \pm 15.5$ & $7.4 \pm 0.2$ & $3.4 \pm 0.3$ & $1.1 \pm 0.1$ & $31.9 \pm 1.0$ & $3.7 \pm 0.4$ \\
\hline \multirow{3}{*}{$\mathrm{ZN}$} & Winter & $113.5 \pm 40.8$ & $20.2 \pm 0.0$ & $-19.0 \pm 64.0$ & $7.0 \pm 0.1$ & $1.7 \pm 0.0$ & $1.3 \pm 0.1$ & $33.2 \pm 1.8$ & $3.6 \pm 0.3$ \\
\hline & Summer & $257.9 \pm 150.8$ & $27.9 \pm 0.0$ & $-196.0 \pm 4.0$ & $7.2 \pm 0.0$ & $1.7 \pm 0.0$ & $1.1 \pm 0.0$ & $36.2 \pm 1.9$ & $3.4 \pm 0.1$ \\
\hline & Fall & $93.9 \pm 29.1$ & $26.3 \pm 0.1$ & $-54.5 \pm 1.5$ & $7.3 \pm 0.1$ & $3.3 \pm 0.1$ & $1.1 \pm 0.0$ & $30.8 \pm 0.6$ & $4.4 \pm 0.2$ \\
\hline \multirow{4}{*}{$\mathrm{BD}$} & Winter & $17.0 \pm 14.0$ & $24.7 \pm 0.1$ & $-54.5 \pm 15.5$ & $7.5 \pm 0.1$ & $1.9 \pm 0.0$ & $1.8 \pm 0.0$ & $18.8 \pm 0.3$ & $0.7 \pm 0.1$ \\
\hline & Spring & $11.3 \pm 10.5$ & $29.5 \pm 0.1$ & $98.5 \pm 5.5$ & $6.9 \pm 0.3$ & $4.8 \pm 0.0$ & $2.8 \pm 0.0$ & $21.2 \pm 0.2$ & $0.8 \pm 0.1$ \\
\hline & Summer & $102.8 \pm 61.6$ & $34.4 \pm 1.7$ & $-20.0 \pm 30.0$ & $7.3 \pm 0.1$ & $1.7 \pm 0.0$ & $1.4 \pm 0.0$ & $23.8 \pm 2.1$ & $1.5 \pm 0.1$ \\
\hline & Fall & $6.6 \pm 7.4$ & $22.6 \pm 0.1$ & $-51.0 \pm 27.0$ & $7.3 \pm 0.3$ & $2.3 \pm 0.0$ & $1.5 \pm 0.1$ & $15.9 \pm 0.2$ & $0.8 \pm 0.1$ \\
\hline \multirow[t]{3}{*}{$\mathrm{BM}$} & Spring & $192.7 \pm 102.2$ & $28.0 \pm 0.1$ & $-281.0 \pm 3.0$ & $6.8 \pm 0.0$ & $7.5 \pm 0.5$ & $2.1 \pm 0.1$ & $32.4 \pm 0.1$ & $1.7 \pm 0.0$ \\
\hline & Summer & $37.4 \pm 12.1$ & $30.3 \pm 0.6$ & $-73.5 \pm 222.5$ & $7.3 \pm 0.1$ & $1.7 \pm 0.1$ & $1.3 \pm 0.0$ & $25.3 \pm 1.6$ & $1.6 \pm 0.0$ \\
\hline & Fall & $49.0 \pm 25.7$ & $24.9 \pm 0.2$ & $22.0 \pm 13.0$ & $7.1 \pm 0.1$ & $3.0 \pm 0.5$ & $1.4 \pm 0.1$ & $27.4 \pm 0.3$ & $2.1 \pm 0.2$ \\
\hline
\end{tabular}




\subsection{Comparisons of Methane Flux and Soil Parameters under Various Conditions}

Soil $\mathrm{CH}_{4}$ fluxes were significantly higher in the mangroves than in the adjoining mudflats at $\mathrm{XF}$, $\mathrm{BD}$, and BM, but not at ZN (Figure 4). Many soil parameters differed between the mangroves and the mudflats at XF and BD (Table 4). Only soil ORP was significantly lower in the mudflats than in the mangroves at $\mathrm{ZN}$. There were no significant differences in the soil parameters between the two habitats at BM.

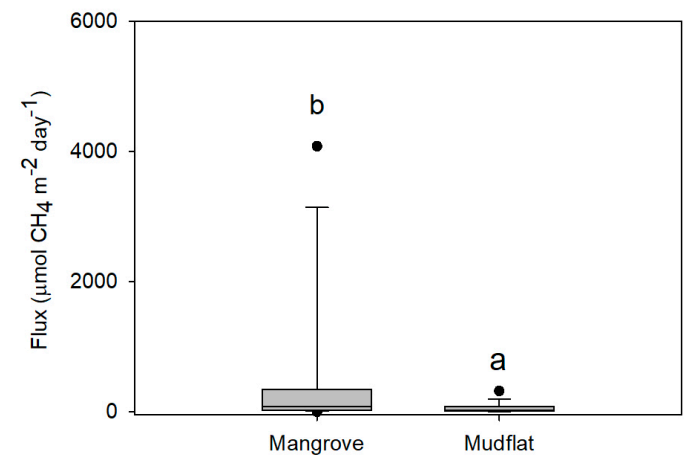

(a) $\mathrm{XF}\left(p\right.$-value $\left.=3.15 \times 10^{-2}\right)$

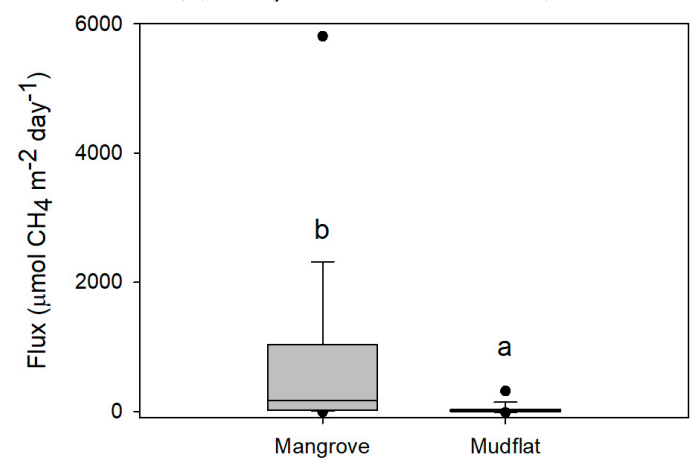

(c) $\mathrm{BD}\left(p\right.$-value $\left.=1.01 \times 10^{-3}\right)$

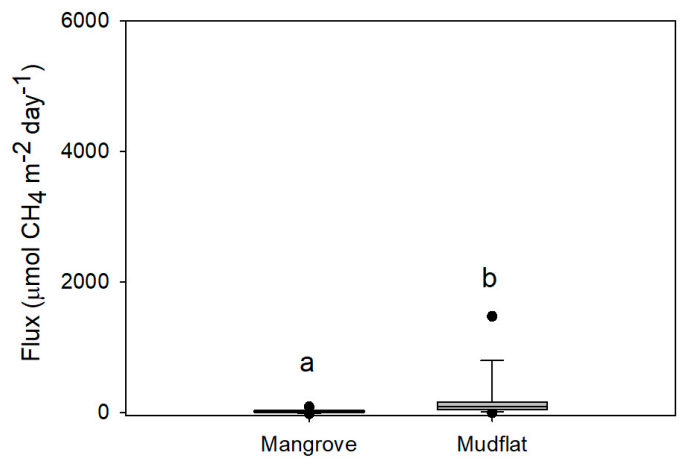

(b) $\mathrm{ZN}\left(p\right.$-value $\left.=1.25 \times 10^{-5}\right)$

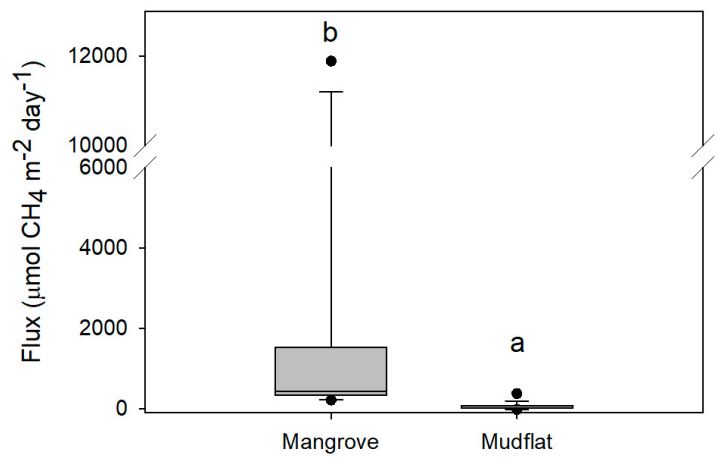

(d) $\mathrm{BM}\left(p\right.$-value $\left.=6.76 \times 10^{-7}\right)$

Figure 4. Comparisons of methane fluxes between mangroves and adjoining mudflats at (a) Xinfeng $(\mathrm{XF}),(\mathbf{b})$ Zhunan $(\mathrm{ZN}),(\mathbf{c})$ Budai $(\mathrm{BD})$, and (d) Beimen (BM). Different letters indicate a significant difference $(p<0.05)$ with the Wilcoxon rank-sum test.

Table 4. Comparisons of methane fluxes and soil parameters between mangroves and adjoining mudflats at the four sites with the Wilcoxon rank-sum test (a significant difference at $p<0.05$; n.s. $=$ no significance). ORP: redox potential.

\begin{tabular}{ccccc}
\hline \multirow{2}{*}{ Parameters } & \multicolumn{3}{c}{ XF } & ZN \\
\cline { 2 - 5 } & $p$-Value & Note & -Value & Note \\
\hline $\mathrm{CH}_{4}$ flux & $3.15 \times 10^{-2}$ & Mangrove $>$ Mudflat & $1.25 \times 10^{-5}$ & Mangrove $<$ Mudflat \\
Temperature & 1.00 & n.s. & 0.89 & n.s. \\
ORP & $3.04 \times 10^{-2}$ & Mangrove $>$ Mudflat & $3.04 \times 10^{-2}$ & Mangrove $>$ Mudflat \\
pH & $2.84 \times 10^{-2}$ & Mangrove $<$ Mudflat & 0.08 & n.s. \\
Salinity & $2.94 \times 10^{-2}$ & Mangrove $<$ Mudflat & 1.00 & n.s. \\
Bulk density & 0.88 & n.s. & 0.07 & n.s. \\
Water content & 0.11 & n.s. & 0.06 & n.s. \\
Organic matter content & $4.08 \times 10^{-2}$ & Mangrove $>$ Mudflat & 0.31 & n.s. \\
\hline
\end{tabular}


Table 4. Cont.

\begin{tabular}{ccccc}
\hline \multirow{2}{*}{ Parameters } & \multicolumn{2}{c}{ BD } & BM \\
\cline { 2 - 5 } & $p$-Value & Note & $p$-Value & Note \\
\hline $\mathrm{CH}_{4}$ flux & $1.01 \times 10^{-3}$ & Mangrove $>$ Mudflat & $6.76 \times 10^{-7}$ & Mangrove $>$ Mudflat \\
Temperature & 0.89 & n.s. & 0.67 & n.s. \\
ORP & $3.04 \times 10^{-2}$ & Mangrove $<$ Mudflat & 0.89 & n.s. \\
pH & 0.06 & n.s. & 0.08 & n.s. \\
Salinity & 0.31 & n.s. & 0.89 & n.s. \\
Bulk density & $2.94 \times 10^{-2}$ & Mangrove $<$ Mudflat & 0.88 & n.s. \\
Water content & $3.04 \times 10^{-2}$ & Mangrove $>$ Mudflat & 1 & n.s. \\
Organic matter content & $2.94 \times 10^{-2}$ & Mangrove $>$ Mudflat & 0.31 & \\
\hline
\end{tabular}

$\mathrm{CH}_{4}$ fluxes were significantly higher in the soils of Avicennia mangroves than in the soils of Kandelia mangroves (Figure 5). ORP and bulk density were lower in the soils of Avicennia mangroves than in the soils of Kandelia mangroves (Table 5). However, $\mathrm{pH}$, salinity, and water content were higher in the soils of Avicennia mangroves than in the soils of Kandelia mangroves. There was no significant difference in organic matter content between the soils of two mangrove species.

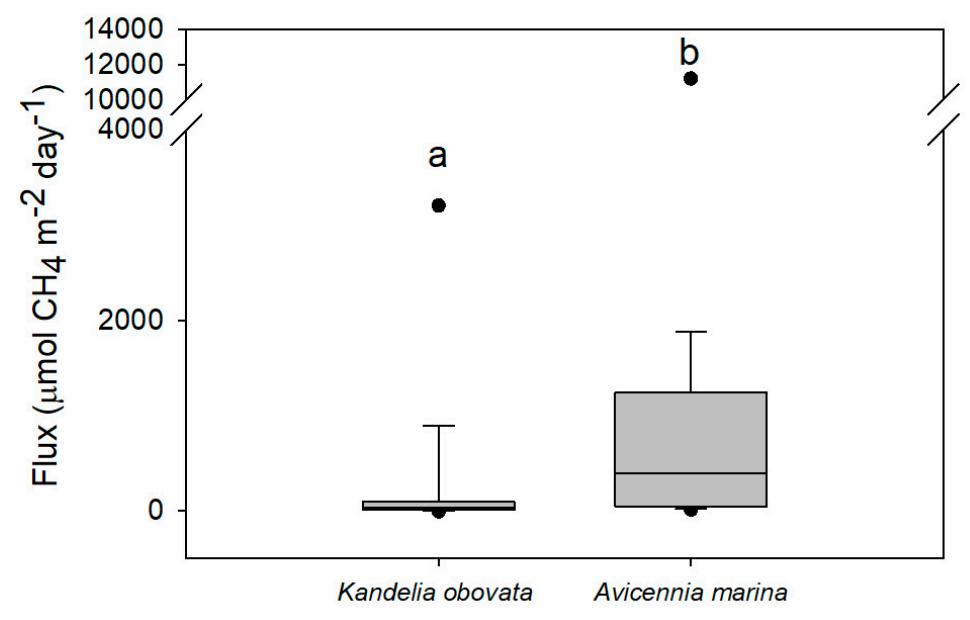

Figure 5. Comparison of methane fluxes between the mangroves of Kandelia obovata and Avicennia marina. Different letters indicate a significant difference $\left(p=1.25 \times 10^{-5}\right)$ with the Wilcoxon rank-sum test.

Table 5. Comparisons of methane fluxes between the mangroves of Kandelia obovata and Avicennia marina with the Wilcoxon rank-sum test (a significant difference at $p<0.05 ;$ n.s. $=$ no significance). ORP: redox potential.

\begin{tabular}{ccc}
\hline Parameters & $p$-Value & Note \\
\hline $\mathrm{CH}_{4}$ flux & $1.56 \times 10^{-5}$ & $\mathrm{~K}<\mathrm{A}$ \\
Temperature & $4.94 \times 10^{-3}$ & $\mathrm{~K}<\mathrm{A}$ \\
ORP & $4.14 \times 10^{-13}$ & $\mathrm{~K}>\mathrm{A}$ \\
$\mathrm{pH}$ & $9.33 \times 10^{-6}$ & $\mathrm{~K}<\mathrm{A}$ \\
Salinity & $1.61 \times 10^{-9}$ & $\mathrm{~K}<\mathrm{A}$ \\
Bulk density & $1.17 \times 10^{-2}$ & $\mathrm{~K}>\mathrm{A}$ \\
Water content & $1.81 \times 10^{-5}$ & $\mathrm{~K}<\mathrm{A}$ \\
Organic matter content & 0.84 & n.s. \\
\hline
\end{tabular}

The results of multiple regressions indicate that water content ( $p$-value $=0.030$ ) and organic matter content $\left(p\right.$-value $=0.038$ ) significantly affected the $\mathrm{CH}_{4}$ fluxes in the soils of Kandelia mangroves. However, none of the soil parameters were detected to significantly influence the $\mathrm{CH}_{4}$ fluxes in the soils of Avicennia mangroves. 


\section{Discussion}

A significant amount of $\mathrm{CH}_{4}$ was emitted from the studied mangrove soils, which indicates that mangrove soils might act as $\mathrm{CH}_{4}$ sources. Seasonal variations in $\mathrm{CH}_{4}$ flux and soil parameters were detected in the mangrove soils at BD and BM. Previous studies also reported a seasonal pattern in other mangrove soils $[15,27,28]$. The highest and lowest $\mathrm{CH}_{4}$ fluxes were observed in warm seasons (spring and summer) and in winter respectively, in this study and in other studies $[13,14,29]$. Previous findings stated that temperature was the main physical factor that affected the amount of $\mathrm{CH}_{4}$ emission $[15,27,30,31]$. However, the present study demonstrates that $\mathrm{CH}_{4}$ fluxes did not vary distinctly among seasons in the mangrove soils at XF and ZN or in the mudflats at the four studied sites. Since seasonal variations in the soil parameters were not detected in the mudflats, it can be expected that the variations in $\mathrm{CH}_{4}$ fluxes $\left(6.6-334.5 \mu \mathrm{mol}-\mathrm{CH}_{4} \mathrm{~m}^{-2}\right.$ day $\left.{ }^{-1}\right)$ from the mudflats were small when compared with those from the mangrove soils (Tables 2 and 3 ).

In the present study, when comparing the $\mathrm{CH}_{4}$ fluxes from the mangrove soils with the adjoining mudflats, there were no clear patterns in the studied mangroves. Each mangrove might have its own characteristics. Since greenhouse gases from soils are produced during microbial processes and respiration, the soil parameters (temperature, redox potential, $\mathrm{pH}$, salinity, density, water content, and organic matter content) related to microbial activities are essential [15,31-34]. At XF, although a lower ORP was found in the mudflats (mudflat: $-62.0-62.5 \mathrm{mV}$, forest: $160.6-218.2 \mathrm{mV}$ ), organic matter content (mudflats: $3.2 \%-3.9 \%$, mangroves: $3.9 \%-5.5 \%$ ) was greater in the mangrove soils, which indicates that more organic compounds were decomposed and more $\mathrm{CH}_{4}$ was produced from the mangrove soils. Allen et al. [27] also found that the degradation of more organic matter contents induced a higher production of $\mathrm{CH}_{4}$. Furthermore, $\mathrm{CH}_{4}$ emissions might be inhibited by the higher salinity in the mudflats (mudflats: 1.7-3.4, mangroves: 0.4-1.2). Several studies demonstrated that higher salinity had an inhibitory effect on methanogenic bacterial activities $[14,15,27,28,35,36]$.

At $\mathrm{ZN}$, the higher ORP in the soils of mangroves under aerobic conditions (mudflat: $-196.0-19.0 \mathrm{mV}$, mangrove: $-3.6-152.2 \mathrm{mV}$ ) might play a major role in affecting the $\mathrm{CH}_{4}$ fluxes in the mangroves. Previous studies have identified that redox potential has inverse effects on $\mathrm{CH}_{4}$ emissions [35,37]. At BD, the lower ORP (mudflats: -54.5 to $98.5 \mathrm{mV}$, mangroves: -340.8 to $-274.4 \mathrm{mV}$ ) and bulk densities (mudflats: 1.4 to $2.8 \mathrm{~g} \mathrm{~cm}^{-3}$, mangroves: 0.5 to $1.1 \mathrm{~g} \mathrm{~cm}^{-3}$ ) and the higher water content (mudflats: $15.9 \%$ to $23.8 \%$, mangroves: $37.8 \%$ to $58.0 \%$ ) and organic matter (mudflats: $0.7 \%$ to $1.5 \%$, mangroves: $5.3 \%$ to $8.4 \%$ ) led to anaerobic conditions in the mangrove soils, and this then resulted in more $\mathrm{CH}_{4}$ emissions from the mangrove soils than from the mudflats. Nevertheless, in the present study, the key environmental factors influencing the differences in $\mathrm{CH}_{4}$ fluxes between the mangrove soils and the mudflats were not found at BM. It appeared that different mangrove tree species might affect $\mathrm{CH}_{4}$ emissions. Our results show that $\mathrm{CH}_{4}$ emissions were significantly higher in the mangrove soils of Avicennia than in the adjoining mudflats; this trend, however, was not necessarily recapitulated at Kandelia.

The results in the present study demonstrate that $\mathrm{CH}_{4}$ fluxes might be different for the same mangrove species. Since there were more anthropogenic activities at XF than at ZN, higher nutrients and more organic compounds were input from the upstream river to the Kandelia mangroves. As a result, a large amount of $\mathrm{CH}_{4}$ was emitted from the mangrove soils at XF. Previous findings also verified that anthropogenic activities caused a greater amount of nutrient input (total organic carbon, total nitrogen, and total phosphorus) that accumulated in mangrove soils; thus, there might be more organic matter that was taken up by microbial metabolism and produced more $\mathrm{CH}_{4}[13,31,38]$. A previous study demonstrated that different mangrove species and related root structures affected greenhouse gases emission [14,27]. The pneumatophores of Avicennia marina might become a pathway that transported $\mathrm{CH}_{4}$ from deeper soils to the atmosphere [14,27,35,39]. In addition, Allen et al. [27] observed that the redox potential of Avicennia marina soils was negative, which led to the development of an anaerobic environment in the soils. The results of previous studies support our findings that the soils of Avicennia mangroves produced more $\mathrm{CH}_{4}$ than the soils of Kandelia mangroves. The results of multiple regression 
analyses show that water and organic matter content in the soils were the main factors regulating $\mathrm{CH}_{4}$ emissions from the Kandelia mangroves. In addition, since bulk density was related to water content in the soils, which might affect the redox potential, this suggests that soil conditions with lower bulk density presented higher water content. As a result, the water and organic matter content contributed significantly to the $\mathrm{CH}_{4}$ emissions in the Kandelia mangroves. However, the results of multiple regression analyses indicate that the assessed soil parameters did not influence the $\mathrm{CH}_{4}$ emissions significantly in the Avicennia mangroves. Since the pneumatophores can transport $\mathrm{CH}_{4}$ from anaerobic deep soils, it is likely that the pneumatophores of Avicennia marina played a more important role than soil parameters in affecting soil $\mathrm{CH}_{4}$ fluxes. Nevertheless, these results are inconsistent with other research which demonstrated that pneumatophores reduced $\mathrm{CH}_{4}$ emissions [40,41]. The role of pneumatophores and the mechanisms of transporting $\mathrm{CH}_{4}$ warrant further investigation.

When comparing this study with other mangrove studies, soil $\mathrm{CH}_{4}$ fluxes (Kandelia obovata: 0.9-884.4, Avicennia marina: $6.7-5071.1 \mu \mathrm{g} \mathrm{m}^{-2} \mathrm{~h}^{-1}$ ) in this study and other mangroves were comparable (Table 6). Thus, the $\mathrm{CH}_{4}$ fluxes in mangrove ecosystems cannot be neglected when constructing the carbon budgets and estimating the carbon storage capacity.

Table 6. Comparisons of soil $\mathrm{CH}_{4}$ flux in the mangroves of this study and other studies.

\begin{tabular}{|c|c|c|c|c|}
\hline Site & Climate & $\begin{array}{c}\text { Dominant Mangrove } \\
\text { Species }\end{array}$ & $\begin{array}{l}\mathrm{CH}_{4} \text { Fluxes } \\
\left(\mu \mathrm{g} \mathrm{m}^{-2} \mathrm{~h}^{-1}\right)\end{array}$ & References \\
\hline $\mathrm{XF}$ and $\mathrm{ZN}$ & Subtropical & Kandelia obovata & $0.9-884.4$ & \multirow{2}{*}{ This study } \\
\hline $\mathrm{BD}$ and $\mathrm{BM}$ & Tropical & Avicennia marina & $6.7-5071.1$ & \\
\hline $\begin{array}{l}\text { North Sulawesi, } \\
\text { Indonesia }\end{array}$ & Equatorial & $\begin{array}{l}\text { Rhizophora apiculate and } \\
\text { Bruguiera gymnorrhiza }\end{array}$ & $0-210.24$ & [42] \\
\hline $\begin{array}{l}\text { Dar es Salaam, } \\
\text { Tanzania }\end{array}$ & Humid tropical & $\begin{array}{c}\text { Sonneratia alba, } \\
\text { Avicenniamarina, Ceriops } \\
\text { tagal, Rhizophora mucronata }\end{array}$ & $7-233$ & [40] \\
\hline $\begin{array}{l}\text { Ceará state, } \\
\text { NE-Brazil }\end{array}$ & Tropical & Rhizophora spp. & $0.7-8.8$ & [13] \\
\hline Odisha state, India & Tropical & Avicennia spp. & $80-2300$ & [28] \\
\hline $\begin{array}{l}\text { Queensland, } \\
\text { Australia }\end{array}$ & Tropical & NA & $26.7-698$ & [36] \\
\hline Shenzhen, China & $\begin{array}{l}\text { Subtropical } \\
\text { monsoonal }\end{array}$ & Kandelia obovata & 190.6-4390.9 & [31] \\
\hline $\begin{array}{l}\text { Moreton Bay, } \\
\text { Australia }\end{array}$ & Subtropical & Avicennia marina & $20-350$ & [32] \\
\hline Chelmer, Australia & Subtropical & Avicennia marina & $3.0-17,370.0$ & [27] \\
\hline $\begin{array}{l}\text { Southeast } \\
\text { Queensland, } \\
\text { Australia }\end{array}$ & Subtropical & Avicennia spp. & $47-1570$ & [14] \\
\hline
\end{tabular}

Note: Table was adapted from Nóbrega et al. [13].

\section{Conclusions}

In this study, $\mathrm{CH}_{4}$ fluxes and soil properties of the top $10 \mathrm{~cm}$ layer were determined in subtropical (Kandelia obovata) and tropical (Avicennia marina) mangrove ecosystems of Taiwan for a complete seasonal cycle. $\mathrm{CH}_{4}$ emissions were observed in the studied mangrove soils, which indicates that mangrove soils might act as $\mathrm{CH}_{4}$ sources. This suggests that $\mathrm{CH}_{4}$ fluxes in mangrove ecosystems cannot be neglected when constructing the carbon budgets and estimating the carbon storage capacity. Our results also indicated that $\mathrm{CH}_{4}$ fluxes were significantly greater in summer than in winter from the Avicennia soils, but no seasonal variation was detected from the Kandelia soils. $\mathrm{CH}_{4}$ fluxes were significantly higher in the mangrove soils of Avicennia than in the adjoining mudflats; this trend, 
however, was not necessarily recapitulated at Kandelia. Multiple regression analyses demonstrated that water and organic matter content were the key factors regulating the $\mathrm{CH}_{4}$ fluxes from the Kandelia soils. However, the assessed soil parameters did not significantly influence the $\mathrm{CH}_{4}$ fluxes from the Avicennia soils. Since pneumatophores can transport $\mathrm{CH}_{4}$ from anaerobic deep soils, this study suggests that the pneumatophores of Avicennia marina played a more important role than soil properties in soil $\mathrm{CH}_{4}$ fluxes. Our results indicated that different mangrove tree species and related root structures may affect soil greenhouse gas emissions.

Author Contributions: Conceptualization, H.-J.L.; Data curation, C.-W.L., Y.-C.K., M.-C.C., H.-H.W., and C.-W.H.; Formal analysis, C.-W.L. and C.-W.H.; Funding acquisition, H.-J.L.; Investigation, C.-W.L., Y.-C.K., M.-C.C., H.-H.W., and C.-W.H.; Methodology, H.-J.L.; Project administration, H.-J.L.; Supervision, H.-J.L.; Validation, C.-W.H. and H.-J.L.; Writing, C.-W.L. and H.-J.L. All authors have read and agreed to the published version of the manuscript.

Funding: The study was granted by the Ministry of Science and Technology (MOST) of Taiwan (106-2621-M-005-005-MY3) and the "Innovation and Development Center of Sustainable Agriculture" from The Featured Areas Research Center Program within the Higher Education Sprout Project by the Ministry of Education (MOE) of Taiwan.

Acknowledgments: We are grateful for the support of the Ministry of Science and Technology (MOST) of Taiwan under grant no. 106-2621-M-005-005-MY3. This work was also financially supported in part by the "Innovation and Development Center of Sustainable Agriculture" from The Featured Areas Research Center Program within the Higher Education Sprout Project by the Ministry of Education (MOE) of Taiwan.

Conflicts of Interest: The authors declare no conflicts of interest.

\section{References}

1. Lin, B.B.; Dushoff, J. Mangrove filtration of anthropogenic nutrients in the Rio Coco Solo, Panama. Manag. Environ. Qual. Int. J. 2004, 15, 131-142. [CrossRef]

2. Vermaat, J.E.; Thampanya, U. Mangroves mitigate tsunami damage: A further response. Estuar. Coast. Shelf Sci. 2006, 69, 1-3. [CrossRef]

3. Guannel, G.; Arkema, K.; Ruggiero, P.; Verutes, G. The power of three: Coral reefs, seagrasses and mangroves protect coastal regions and increase their resilience. PLoS ONE 2016, 11, e0158094. [CrossRef] [PubMed]

4. Hochard, J.P.; Hamilton, S.; Barbier, E.B. Mangroves shelter coastal economic activity from cyclones. Proc. Natl. Acad. Sci. USA 2019, 116, 12232-12237. [CrossRef]

5. Barbier, E.B. Valuing the environment as input: Review of applications to mangrove-fishery linkages. Ecol. Econ. 2000, 35, 47-61. [CrossRef]

6. Diele, K.; Koch, V.; Saint-Paul, U. Population structure, catch composition and CPUE of the artisanally harvested mangrove crab Ucides cordatus (Ocypodidae) in the Caeté estuary, North Brazil: Indications for overfishing? Aquat. Living Resour. 2005, 18, 169-178. [CrossRef]

7. Mumby, P.J.; Edwards, A.J.; Arias-González, J.E.; Lindeman, K.C.; Blackwell, P.G.; Gall, A.; Gorczynska, M.I.; Harborne, A.R.; Pescod, C.L.; Renken, H.; et al. Mangroves enhance the biomass of coral reef fish communities in the Caribbean. Nature 2004, 427,533-536. [CrossRef]

8. Donato, D.C.; Kauffman, J.B.; Murdiyarso, D.; Kurnianto, S.; Stidham, M.; Kanninen, M. Mangroves among the most carbon-rich forests in the tropics. Nat. Geosci. 2011, 4, 293-297. [CrossRef]

9. Mcleod, E.; Chmura, G.L.; Bouillon, S.; Salm, R.; Björk, M.; Duarte, C.M.; Lovelock, C.E.; Schlesinger, W.H.; Silliman, B.R. A blueprint for blue carbon: Toward an improved understanding of the role of vegetated coastal habitats in sequestering $\mathrm{CO}_{2}$. Front. Ecol. Environ. 2011, 9, 552-560. [CrossRef]

10. Serrano, O.; Lovelock, C.E.; Atwood, T.B.; Macreadie, P.I.; Canto, R.; Phinn, S.; Arias-Ortiz, A.; Bai, L.; Baldock, J.; Bedulli, C.; et al. Australian vegetated coastal ecosystems as global hotspots for climate change mitigation. Nat. Commun. 2019, 10,1-10. [CrossRef]

11. Li, C.; Mosier, A.; Wassmann, R.; Cai, Z.; Zheng, X.; Huang, Y.; Tsuruta, H.; Boonjawat, J.; Lantin, R. Modeling greenhouse gas emissions from rice-based production systems: Sensitivity and upscaling. Glob. Biogeochem. Cycles 2004, 18. [CrossRef] 
12. Alongi, D.M.; Wattayakorn, G.; Pfitzner, J.; Tirendi, F.; Zagorskis, I.; Brunskill, G.J.; Clough, B.F. Organic carbon accumulation and metabolic pathways in sediments of mangrove forests in southern Thailand. Mar. Geol. 2001, 179, 85-103. [CrossRef]

13. Nóbrega, G.N.; Ferreira, T.O.; Neto, M.S.; Queiroz, H.M.; Artur, A.G.; Mendonça, E.D.S.; Silva, E.D.O.; Otero, X.L. Edaphic factors controlling summer (rainy season) greenhouse gas emissions $\left(\mathrm{CO}_{2}\right.$ and $\left.\mathrm{CH}_{4}\right)$ from semiarid mangrove soils (NE-Brazil). Sci. Total Environ. 2016, 542, 685-693. [CrossRef] [PubMed]

14. Allen, D.; Dalal, R.C.; Rennenberg, H.; Schmidt, S. Seasonal variation in nitrous oxide and methane emissions from subtropical estuary and coastal mangrove sediments, Australia. Plant Biol. 2011, 13, 126-133. [CrossRef] [PubMed]

15. Chen, G.; Chen, B.; Yu, D.; Tam, N.F.; Ye, Y.; Chen, S. Soil greenhouse gas emissions reduce the contribution of mangrove plants to the atmospheric cooling effect. Environ. Res. Lett. 2016, 11, 124019. [CrossRef]

16. Bouillon, S.; Borges, A.V.; Castañeda-Moya, E.; Diele, K.; Dittmar, T.; Duke, N.C.; Kristensen, E.; Lee, S.Y.; Marchand, C.; Middelburg, J.J.; et al. Mangrove production and carbon sinks: A revision of global budget estimates. Glob. Biogeochem. Cycles 2008, 22. [CrossRef]

17. Li, S.B.; Chen, P.H.; Huang, J.S.; Hsueh, M.L.; Hsieh, L.Y.; Lee, C.L.; Lin, H.J. Factors regulating carbon sinks in mangrove ecosystems. Glob. Chang. Boil. 2018, 24, 4195-4210. [CrossRef]

18. IPCC. Climate Change: The Physical Science Basis. In Contribution of Working Group I to the Fifth Assessment Report of the Intergovernmental Panel on Climate Change; Stocker, T.F., Qin, D., Plattner, G.K., Tignor, M., Allen, S.K., Boschung, J., Nauels, A., Xia, Y., Bex, V., Midgley, P.M., Eds.; Cambridge University Press: Cambridge, UK; New York, NY, USA, 2013; 1535p.

19. Cameron, C.; Hutley, L.B.; Friess, D.A. Estimating the full greenhouse gas emissions offset potential and profile between rehabilitating and established mangroves. Sci. Total Environ. 2019, 665, 419-431. [CrossRef] [PubMed]

20. Sasmito, S.D.; Taillardat, P.; Clendenning, J.N.; Cameron, C.; Friess, D.A.; Murdiyarso, D.; Hutley, L.B. Effect of land-use and land-cover change on mangrove blue carbon: A systematic review. Glob. Chang. Boil. 2019, 25, 4291-4302. [CrossRef]

21. Faunce, C.H.; Layman, C.A. Sources of variation that affect perceived nursery function of mangroves. In Nagelkerken I (ed) Ecological Connectivity Among Tropical Coastal Ecosystems; Media, B.V., Ed.; Springer: New York, NY, USA, 2009; pp. 401-421.

22. Pai, S.C.; Yang, C.C.; Riley, J.P. Formation kinetics of the pink azo dye in the determination of nitrite in natural waters. Anal. Chim. Acta 1990, 232, 345-349. [CrossRef]

23. Jenkins, D.; Medsker, L.L. Brucine Method for the Determination of Nitrate in Ocean, Estuarine, and Fresh Waters. Anal. Chem. 1964, 36, 610-612. [CrossRef]

24. Pai, S.C.; Tsau, Y.J.; Yang, T.I. pH and buffering capacity problems involved in the determination of ammonia in saline water using the indophenol blue spectrophotometric method. Anal. Chim. Acta 2001, 434, 209-216. [CrossRef]

25. Murphy, J.A.M.E.S.; Riley, J.P. A modified single solution method for the determination of phosphate in natural waters. Anal. Chim. Acta 1962, 27, 31-36. [CrossRef]

26. R Core Team. R: A Language and Environment for Statistical Computing. Available online: http: //www.R-project.org (accessed on 11 February 2020).

27. Allen, D.E.; Dalal, R.C.; Rennenberg, H.; Meyer, R.L.; Reeves, S.; Schmidt, S. Spatial and temporal variation of nitrous oxide and methane flux between subtropical mangrove sediments and the atmosphere. Soil Biol. Biochem. 2007, 39, 622-631. [CrossRef]

28. Chauhan, R.; Datta, A.; Ramanathan, A.L.; Adhya, T.K. Factors influencing spatio-temporal variation of methane and nitrous oxide emission from a tropical mangrove of eastern coast of India. Atmos. Environ. 2015, 107, 95-106. [CrossRef]

29. Chen, G.C.; Nora, F.Y.; Tamb, Y.Y. Spatial and seasonal variations of atmospheric $\mathrm{N}_{2} \mathrm{O}$ and $\mathrm{CO}_{2}$ fluxes from a subtropical mangrove swamp and their relationships with soil characteristics. Soil Biol. Biochem. 2012, 48, 175-181. [CrossRef]

30. Purvaja, R.; Ramesh, R. Natural and anthropogenic methane emission from coastal wetlands of South India. Environ. Manag. 2001, 27, 547-555. [CrossRef]

31. Chen, G.C.; Tam, N.F.Y.; Ye, Y. Summer fluxes of atmospheric greenhouse gases $\mathrm{N}_{2} \mathrm{O}, \mathrm{CH}_{4}$ and $\mathrm{CO}_{2}$ from mangrove soil in South China. Sci. Total Environ. 2010, 408, 2761-2767. [CrossRef] 
32. Kreuzwieser, J.; Buchholz, J.; Rennenberg, H. Emission of methane and nitrous oxide by Australian mangrove ecosystems. Plant Biol. 2003, 5, 423-431. [CrossRef]

33. Lekphet, S.; Nitisoravut, S.; Adsavakulchai, S. Estimating methane emissions from mangrove area in Ranong Province, Thailand. Songklanakarin J. Sci. Technol. 2005, 27, 153-163.

34. Huang, B.; Yu, K.; Gambrell, R.P. Effects of ferric iron reduction and regeneration on nitrous oxide and methane emissions in a rice soil. Chemosphere 2009, 74, 481-486. [CrossRef] [PubMed]

35. Livesley, S.J.; Andrusiak, S.M. Temperate mangrove and salt marsh sediments are a small methane and nitrous oxide source but important carbon store. Estuar. Coast. Shelf Sci. 2012, 97, 19-27. [CrossRef]

36. Rosentreter, J.A.; Maher, D.T.; Erler, D.V.; Murray, R.; Eyre, B.D. Factors controlling seasonal $\mathrm{CO}_{2}$ and $\mathrm{CH}_{4}$ emissions in three tropical mangrove-dominated estuaries in Australia. Estuar. Coast. Shelf Sci. 2018, 215, 69-82. [CrossRef]

37. Yu, K.; Faulkner, S.P.; Patrick, W.H., Jr. Redox potential characterization and soil greenhouse gas concentration across a hydrological gradient in a Gulf coast forest. Chemosphere 2006, 62, 905-914. [CrossRef]

38. Kristensen, E.; Bouillon, S.; Dittmar, T.; Marchand, C. Organic carbon dynamics in mangrove ecosystems: A review. Aquat. Bot. 2008, 89, 201-219. [CrossRef]

39. Krithika, K.; Purvaja, R.; Ramesh, R. Fluxes of methane and nitrous oxide from an Indian mangrove. Curr. Sci. 2008, 94, 218-224.

40. Kristensen, E.; Flindt, M.R.; Ulomi, S.; Borges, A.V.; Abril, G.; Bouillon, S. Emission of $\mathrm{CO}_{2}$ and $\mathrm{CH}_{4}$ to the atmosphere by sediments and open waters in two Tanzanian mangrove forests. Mar. Ecol. Prog. Ser. 2008, 370, 53-67. [CrossRef]

41. He, Y.; Guan, W.; Xue, D.; Liu, L.; Peng, C.; Liao, B.; Hu, J.; Yang, Y.; Wang, X.; Zhou, G. Comparison of methane emissions among invasive and native mangrove species in Dongzhaigang, Hainan Island. Sci. Total Environ. 2019, 697, 133945. [CrossRef]

42. Chen, G.C.; Ulumuddin, Y.I.; Chen, S.Y.; Chen, B.; Ye, Y.; Ou, D.Y.; Ma, Z.Y.; Huang, H.; Wang, J.K. Rich soil carbon and nitrogen but low atmospheric greenhouse gas fluxes from North Sulawesi mangrove swamps in Indonesia. Sci. Total Environ. 2014, 487, 91-96. [CrossRef] 